\title{
The Limited Influence of Right-Wing Movements on Social Media User Engagement
}

\author{
Carsten Schwemmer ${ }^{1,2}$
}

Accepted for publication at journal Social Media + Society, July 282021

${ }^{1}$ GESIS - Leibniz Institute for the Social Sciences. Computational Social Science Department.

${ }^{2}$ University of Bamberg, Chair for Political Sociology.

Contact: Email: c.schwem2er@gmail.com, Twitter: @c_schwemmer

\begin{abstract}
:
This paper generates new insights into the dynamic interplay between social media content generated by right-wing movements, user engagement and the public attention movements receive. I argue that movement leaders seek to achieve high user engagement for utilizing mechanisms of information diffusion in order to increase both online and on-site mobilization. In a case study, I analyze the German right-wing movement Pegida, which uses Facebook for spreading its anti-Islam agenda online. Data from Pegida's Facebook page are combined with news reports over a period of 18 months to measure activity on Facebook and in the public sphere simultaneously. Results of quantitative text and time series analysis show that Pegida cannot influence user engagement by simply creating more posts. Instead, it is the content of posts that matters. Moreover, findings highlight a strong connection between Facebook activities and the public sphere. In times of decreasing attention, the movement changes its social media strategy in response to exogenous shocks: Pegida resorts increasingly to radical mobilization methods by posting xenophobic content that is more likely to incite users to engage on Facebook.
\end{abstract}

Keywords: right-wing movements, social media, computational social science,

Facebook, user engagement 


\section{Introduction}

The use of social media to mobilize participants has become more common for political movements and protest groups in the past few years. Similarly, radical right-wing and populist forces have increasingly gained influence in many Western-European countries (Arzheimer 2015). Previous research showed that social media played an important role for this development and results of several studies indicate that online representations of social movements are no isolated bubbles of interaction, but instead do affect on-site user mobilization (Budak and Watts 2015, Poell et al. 2016). This work specifically investigates how right-wing movements use social media sites for reaching their desired audience. Moreover, I examine to what extend right-wing movements can influence user engagement, which in turn can accelerate the diffusion of xenophobic propaganda online. Specifically, this paper aims to answer the following research questions:

RQ1: What factors influence the activity of right-wing movement supporters on social media platforms?

RQ2: How do right-wing movements adjust their social media content over time?

These questions will be examined empirically by analyzing the social media activities of the right-wing populist movement Pegida. Starting as a Facebook group in 2014, the political movement "Patriotic Europeans Against the Islamization of the West" - in short Pegida organized weekly demonstrations in the German town Dresden to protest against the allegedly ongoing Islamization of Germany and policy decisions related to the refugee crisis (Dostal 2015). To organize street-rallies, communicate with sympathizers and distribute its anti-Islam agenda on the Internet, Pegida uses the social networking site Facebook, where the movement reached over 100.000 likes within a few months (Patzelt 2016b, 140). To analyze activity on Facebook and in the public sphere simultaneously, I combine data from Pegida's Facebook page with news reports from digital archives over a period of 18 months from December 2014 until May 2016. This research design allows to shed light on the relation between Pegida`s 
social media activities and the public attention they receive. Results suggest that user activity on Facebook is strongly connected to public attention. At the same time, Pegida cannot influence user engagement by simply creating more posts. Instead, it is the content of posts that matters. Xenophobic posts that are more likely to affect mood or emotion of Facebook users generate substantially more activity than others. In response to exogenous shocks and its decreasing attention in the public sphere, the movement changed its topical focus to more and more xenophobic content, which in turn may have contributed to the declining user base of Pegida. This paper contributes to the literature on social media use by right-wing movements in two ways: first, it demonstrates the benefits of incorporating traditional media sources to better understand online interactions and proposes a research design for future researchers. Second, using the example of Pegida, it sheds light on the ways right-wing movements use social media for mobilization and demonstrates the limited influence of the movement on the engagement of Facebook users.

\section{Theoretical work on social movements}

A large body of literature highlights that in order to reach their goal of achieving social change, social movements are constantly examining ways to mobilize motivated people for their cause and to gain access to more resources (Opp, 2009). In order to be successful at mobilization either on the streets or online (Van Laer \& Van Aelst 2010) - factors like a group's resources, its common interests and shared identity, as well as its political power and available resources play a vital role (Harlow 2012; Tilly 1978). Online platforms are powerful tools in this regard. Social media pages enable transnational communication to reach potential supporters and only require limited resource investment. Moreover, communication between movement organizers and followers enhances the shaping of a collective identity and connects users according to their ideological beliefs (Van de Donk et al. 2004, 5ff.). While materialistic and rational-choice based theories lay important ground for understanding social movements and protest behavior, they fall short in addressing two aspects that are of particular importance for this work. First, scholars 
highlight their inefficiency to incorporate emotional dynamics (Jasper 2011). Jasper argues that emotions are present in every aspect of protest and that they shape stated and unstated goals of social movements $(2011,286)$. Emotions can both affect behavior of a movement`s leadership and potential supporters. At the same time, a movement can act strategically to stipulate emotions such as fear or anger for mobilization purposes.

This is related to the second shortcoming of beforementioned theories, neglecting the importance of strategic and tactical leadership. In the words of Ganz: "Social movement scholars tell us little about the relationship of strategic leadership to social movement success. Explanations of the emergence, development, and outcomes of social movements are usually based on variation in resources, opportunities, and framing [..] - concepts that stress the influence of environmental change on actors." (Ganz 2000, 1008f). Furthermore, past work highlights the connection between both concepts: "Activists strategize about what kinds of emotions to display, as well as what kinds of emotions to try to stimulate in movement participants, targets, and opponents.” (Goodwin et al. 2004). Recent empirical work further emphasizes the potential impact of strategic choices regarding emotional content. Rathje et al. (2021) find that emotional content on social media is a strong driver of user engagement on social media. Furthermore, they show that animosity towards political out-groups - which is also likely to incite emotions - has an even stronger effect. This seems particularly relevant in the context of right-wing actors, as their users seem to be more active than others, which eventually leads to a disproportionate visibility of right-wing content (Gaisbauer et al. 2021). 


\section{Related work on social media representations of right-wing movements}

Scholars have recently examined the use of social media platforms by social movements, showing that networking services like Twitter and Facebook are commonly used to organize social, political and protest movements. Kavada $(2015,872)$ found that "social media helps to blur the boundaries between the inside and the outside of the [occupy] movement" and that social media platforms are important in the process of creating collective identity. Budak and Watts (2015) used Twitter data to analyze party support of users in times of the Gezi uprising. Their results suggest that incorporating time in research design is a crucial factor for understanding dynamics of social movements, which is reflected in the research design of this work. With particular focus on right-wing movements, Stier et al. (2017) compared Facebook use by Pegida and German political parties, showing that both right-wing populist actors, Pegida and the AfD party, appeal to similar target groups. With regards to user engagement, Puschmann et al. (2021) also compared the Facebook pages of Pegida and the AfD party using an inductive computational approach. They find that the prevalence of shared issues such as immigration differed between the two pages in general, but also changed over time. Comparative research has further highlighted the Internet as a crucial communication and recruitment tool for right-wing extremist organizations (Caiani \& Parenti 2016). Krämer (2017) examined the role of the internet for right-wing populism. Among others, he identified the collective organization of information on misconduct of elite and outgroup members (e.g. immigrants) and the construction of threats by spreading anecdotal evidence (e.g. alleged assaults by foreigners). There is also evidence for the form of far-right mobilization to be strongly driven by political opportunity structures (Klein \& Muis 2017). Overall, these studies highlight the importance of social media for disseminating radical right world views. Building upon past work, this paper generates new insights into the dynamic interplay between content generated by right-wing movements, exogenous shocks and the public attention movements receive. 


\section{Attention in the public sphere}

It is reasonable to assume that mobilization potentials of emerging social movements are related to the amount of public attention they receive and to occurring exogenous shocks that can be exploited to push a movement's agenda. However, over the course of their existence, many social movements - including Pegida - suffered from decreasing attention. In that regard, a dynamic salience measure can help to better understand the connection between social media activities and the public sphere. In the context of this work, salience is understood as a measure for tracking received public attention over time. Several methods for measuring issue salience, for instance in the context of political parties, have already been developed over the last decades. Most traditional approaches rely on survey data to measure public opinion (Weaver 1991). It is certainly feasible to analyze the salience of important issues for movements. e.g. for Pegida immigration in Germany (Czymara and Dochow 2018) with survey data. However, capturing salience of social movements themselves by using survey data is not a viable alternative for analyzing emerging movements. Corresponding survey items first would have to be developed and integrated in surveys. As social movements can appear out of nowhere and disappear just as fast, surveys are often too slow. Regarding alternatives, Helbling and Tresch (2011) used a qualitative coding scheme for newspapers and compared the results with other approaches to measuring positions and issue salience of parties. They found that coding media coverage data is resource draining, but nevertheless allows for establishing long-time data series and retrospective data collection. A more recent alternative for capturing issue salience relies on aggregated data from the Google search engine Google Trends. However, the potential of Google Trends depends on the specificity of the search terms used and the method only captures relative trends (Mellon 2013). In summary, survey data are not an adequate method for measuring issue salience or public attention of social movements. The use of media data, e.g. newspaper articles, allows the use of textual content to not only aggregate counts but also to provide additional context information. Both media data and Google Trends enable time series analysis and retrospective data collection, but qualitative coding of media data is very time- 
intensive and Google Trends only provides relative indicators. Because of these shortcomings, I apply a scalable approach based upon digital news archives, which will be described further in the data and methods section.

\section{Mechanisms of content diffusion on Facebook}

In order to derive expectations for the social media use of right-wing movements, it is important to highlight that the activity of users is a crucial factor as it influences how fast and to whom right-wing propaganda can spread on the platform. What are the motives for right-wing movements to stipulate user engagement on social media platforms like Facebook? The mechanisms behind the diffusion of information on Facebook, for instance the diffusion of right-wing propaganda, are of great importance to protest groups. Facebook has a complex, algorithmically driven method of organizing news feeds of users. Information in the network spreads as users interact with content, which can be seen by befriended users. This possibly leads to befriended users also interacting with that content, promoting its diffusion throughout the network. Ultimately, this diffusion dictates how fast and to whom information spreads on social media. In general, Facebook users seem to underestimate their potential reach (Bernstein et al. 2013). Diffusion mechanisms also apply when users interact with pages like the official Pegida page. As users subscribe to a Facebook page, its content will appear in their news feed. A high number of subscribers would benefit Pegida or any other political actor on Facebook because it simplifies distributing content to an already established user base. More importantly, when users engage with a post of a Facebook page through commenting, liking, or sharing, this also increases the probability that this post will appear in other people's news feed (Rieder et al. 2015, 4). Moreover, if friends of a user interact with a Facebook page, this content can also appear on the users' news feed although the user her or himself is not a subscriber. As will be shown in the results section, the Pegida is well aware of information diffusion mechanisms. 
For these reasons, it can be expected that Pegida tries to generate a high quantity of posts, as more content can potentially stimulate more user interaction. In addition, it is reasonable to assume that right-wing movements like Pegida will qualitatively choose topics that either directly affect mobilization on the streets or have the potential to stipulate a lot of user engagement, for instance by triggering emotions such as fear. Furthermore, it can be expected that, besides Facebook content, salience in the public sphere is an important factor for user activity on the platform, as issues covered in traditional media are also likely to increase public interest in corresponding social media channels (RQ1). Regarding expectations for the adjustment of social media content over time, right-wing movements seek to exploit external events if they can be used to warrant their right-wing agenda, which can eventually result in the beforementioned chain of emotions, user engagement and increased potential for on-site mobilization. For the case of the right-wing movement Pegida, it is expected to dynamically adjust its Facebook content in response to important exogenous shocks that are salient in the public sphere so long as such events can be utilized to spread xenophobic and islamophobic content (RQ2).

\section{The right-wing populist movement Pegida}

Since its creation, Pegida very effectively utilized Facebook as a platform for propaganda and mobilization. Within a few months, the movement reached over 100.000 likes on Facebook (Patzelt 2016b) and received international media attention (e.g. Connolly 2014). In addition, Pegida played an important role for the establishment of the right-wing populist party AfD in Germany. To briefly describe its historical development and political agenda at this point, the movement emerged in 2014 and was founded by a small number of citizens living in Saxony, a region in Germany, which has been dominated by conservative politics in the last years (Dostal 2015, 523). Primarily driven by political motives, Pegida supporters fear an alleged Islamization of Western culture. According to Pegida, this Islamization would lead to an 
increasing "alienation" of German culture and language and would increase the danger of religious wars on German territory. For this reason, the movement's supporters claim that the German asylum policy should be more restrictive and delinquent immigrants be deported immediately. Since October 2014, Pegida has been organizing weekly demonstrations in the German city of Dresden to protest against the Islamization of the West. While first events only attracted a low number of participants, the movement quickly experienced an enormous upswing. According to police reports, 25,000 protesters attended an event in January 2015, resulting in even more public interest and media coverage since Pegida's creation. However, following a number of crises the organization has gone through, including a rift between its leaders, Pegida's public attention declined steadily soon after its peak (Dostal 2015, 525f). With a few exceptions, events after October 2015 attracted a somewhat stable number between 2,000 and 3,000, all the way until May 2016.

Two (translated) phrases, often shouted by protesters during demonstrations, were seen as trademarks of Pegida: "We are the People!" illustrated a strong group identity representing ordinary citizens and "Lying press!" referred to news coverage which, according to the Pegida, misrepresented" their actions. Both phrases also have important historical meanings. "Lying press!" was used by the Nazis to agitate against Jewish and leftist newspapers (Gadinger 2019), whereas "We are the People" was shouted during demonstrations in Eastern Germany in 1989 and 1990 (Reiher 2015). These trademark phrases - and Pegida's content in general - are in line with populist views of representing "the people", opposing to "the corrupt elite" (Mudde and Kaltwasser 2017, 4).

Regarding Pegida's supporters, several research teams conducted field studies to survey the protesters and understand why Pegida reached its unexpected public attention (Vorländer et al. 2015, Daphi et al. 2015, Patzelt 2016a). These studies report a rather consistent image of participants being predominantly male, working- and middle-class members with an average age over 50. In comparison to other Germans, Pegida survey participants were ranked as considerably farther right on the political spectrum, ranging from centrist up to extreme right 
(Patzelt 2016b, 160ff). Regarding the content of speeches held by members of the organizers and invited guests at demonstrations, speakers were ranked as clearly islamophobic and xenophobic. Overall, speeches were classified as populist and for most topics radical. Signs of

cultural racism were apparent wherever Muslims were mentioned. While Pegida is unique in the sense that historical backgrounds of Germany are important motives for the movement, it is also typical in that it shares key characteristics with other right-wing populist motives: antielitism, exclusion of outgroups and representation of "the people". In that sense, it provides an ideal example for an emerging right-wing movement that has been using social media since its creation.

\section{Data and Methods}

Data for this work was collected over a period of 18 months between December 2014 and May 2016. The netvizz application (Rieder 2013) was used to connect to the Facebook Application Programming Interface and extract texts and user activity statistics from Pegida's page. In total, 3,752 out of 3,765 posts and corresponding counts for user comments were retrieved. The small number of missing posts could not be extracted due to deletion or removal from Facebook. The data includes all content generated by the Pegida's administrators and user activity was measured with all comments on these posts. Despite comments, likes and shares are also important indicators of user engagement. Kümpel et al. (2015) reviewed a large body of research articles about sharing behavior in the context of news. While many of these articles provide evidence for the importance of sharing, Kümpel et al. highlight important limitations in the literature. Among other concerns, they draw attention to the lack of focus on network perspectives and platform structures to better explain sharing behavior. For the majority of analysis, I predominantly focus on comments instead of shares or likes as commenting can be done repeatedly. Every comment in turn raises the chance of visibility and therefore affects mechanisms for information diffusion (Bene 2017, 6). In addition, some robustness checks 
related to likes and shares are discussed in the results section. To capture Pegida's salience over time, I automated a procedure for extracting and processing data from the LexisNexis archive. LexisNexis is a digital news archive including local newspapers and magazines, but also major world publications like the Guardian. The use of LexisNexis is not without limitations, as the archive does not cover every major news outlet in Germany. In addition, LexisNexis is restricted to print media, excluding audiovisual media such as podcasts and videos. For this reason, the data source is far from a perfect representation of the public sphere. In the context of this work, it is nevertheless sufficient to examine communication dynamics over time. From LexisNexis, I extracted articles of 116 available German news sources, which included Pegida as a subject term to create a dataset of 24,279 news articles. As a robustness check, I handcoded 100 randomly sampled articles and found only 7 texts that were not related to Pegida. An overview of the top 50 sources and corresponding number of articles is available in Supplementary Appendix A. Out of this dataset, aggregated daily counts for the number of news articles related to Pegida are used to analyze its salience over time.

In addition, all news reports are analyzed to understand time-dependent context of Pegida articles. For this purpose, the time period of the dataset is split into intervals of three months length. Afterwards a support vector machine (Crammer and Singer 2001) is trained on the time interval categories. Support vector machines are supervised models learning from features with the most predictive power for some categories of interest. This allows to discover the most important terms for correctly classifying an article as being published in the corresponding interval. The model further allows to examine issue-related content over time without the need of hand-coding or similar resource intensive procedures. In conjunction with aggregated daily counts for the number of news articles related to Pegida, this provides a measure of contextenriched attention towards Pegida in the news.

For automated text analysis, corresponding texts first are processed into a corpus with common methods of text preprocessing (Grimmer and Stewart 2012): documents are treated as bags of 
words and terms were reduced to their stem form. In addition, stop words with no semantic meaning were removed from the corpus.

As for the interplay between Pegida's Facebook content, user activity and salience over time, correlations and granger causality tests were applied (Granger 1969). Granger tests are useful to examine whether values of a time series $X$ provide more predictive power to forecast the development of another time series $Y$ than by only using lagged values of $Y$. In the context of this paper granger tests are applied to analyze whether either the amount of Facebook content generated by Pegida or its salience in the public sphere substantively influence the activity of Facebook users.

Moreover, to shed light on the determinants of user activity, it is important to not only compare how many posts are generated, or how salient Pegida is over time, but also which topics are discussed on Facebook and whether specific subjects generate more user activity than others. To categorize posts into different topics, a structural topic model was fitted to the corpus (Roberts et al. 2014). Topic models help to automatically discover latent topics from text documents. In these models, a topic can be understood as a set of words representing interpretable themes and documents are represented as a mixture of these topics. For each document, proportions across all topics sum up 100\%. As an example, after fitting a topic model, a post could for instance mostly be capturing a topic "Islamization" with a proportion of $60 \%$, "foreign policy" with $30 \%$ and other topics with $10 \%$. In addition to representing documents as a distribution of topics, structural topic models further allow the inclusion of document-specific covariates that are meaningful to affect both document-topic proportions and word distributions over topics. Drawing on this feature, I incorporated dates of posts as an explanatory covariate to analyze how topic proportions vary over time. While topic models are very useful for reducing the dimensionality of textual data, one disadvantage is that the number of topics must be chosen in advance by the analyst. As the corpus is rather small and a classification into broader themes is more useful for this work than high levels of granularity, a model for ten topics was fitted to the corpus of Pegida posts. ${ }^{1}$ Afterwards, topics were 
examined qualitatively to assign labels by finding representative posts with high proportions for a given topic. Additionally, the FREX metric was utilized, which indicates terms that are both frequent and exclusive for each topic (Lucas et al. 2015, 19). Finally, the most prevalent topics were determined for each post and used in combination with time stamps to model effects of topical content and time on the number of comments each post received. Using a negativebinomial model for comment counts, this allows to analyze whether topic and/or time effects are more meaningful for explaining user activity on Facebook.

\section{Results}

\section{An overview of Pegida content}

Before turning to the research questions for this paper, it is worth providing some descriptive findings about the content Pegida disseminates on Facebook. Inspecting the 100 most common (translated) terms in the posts reveals that Pegida often refers to itself within posts ("\#Pegida"). This can be interpreted as an attempt to manifest a collective identity and is in line with a general populist view of "we down here against the upper class". Many common terms are used in the context of protest mobilization, where Pegida prompts the users to take to the streets (“\#OnTheStreet”) for weekly demonstrations on Monday (“\#MondayIsPegidaDay") at the usual times of ("18,30") in the German city ("Dresden"). Several terms also illustrate Pegida's xenophobic core issues, frequently using terms for Islamization (“\#Islamization”), closing borders ("\#CloseBorders, \#SuspendSchengen") and demands for deportations (“\#GetOutAsylumBetrayers"). References and criticism against politicians, especially the German Chancellor Angela Merkel (“\#MerkelNeedsToDisappear”), are another common theme.

It is also striking that Pegida very frequently uses hashtags within Facebook posts, which mainly serves two purposes: labeling the content with expressions known by its supporters and indexing posts to enlarge their reach on the platform. One might question whether Pegida 
administrators are fully aware of the possibility to search for hashtags on the Facebook platform, which is another important aspect of information diffusion. An exemplary translated post from January 19th of May 2015 shows that they most likely are:

"Thanks Kathrin! You took our view very well and held your ground against the constantly interrupting, aggressive and arrogant CDU politician Spahn. Next time together with Rene or Lutz! This was only the first round which was clearly won by you! \#DresdenShowsHowToDoIt PS: All the stupid comments on some watch-site - for which we do not want to provide reach with links or hashtags - obviously show how they boil with rage because of Kathrin's confident performance. Beforehand, they predicted a big disaster. Well, once again a prove that dogooders just don't have a clue about anything." 2

The post relates to the appearance of a Pegida member, Kathrin Oertel, as a discussant in a German TV show. The text clearly indicates that Pegida knows about the effects of links and hashtags on information diffusion as they explicitly caution against the use of such features to refer to another anti-Pegida Facebook page.

\section{Dynamics of user activity on the platform}

Facebook pages benefit from high rates of user participation because more activity increases the probability of reaching new supporters on the platform. Therefore, organizations like Pegida are encouraged to positively affect user participation, where a straightforward way of doing so is to create more content which users can interact with. This raises the important question of whether Pegida can influence user engagement by simply posting more often. Another important aspect to consider is Pegida's salience as a general public issue. In times were Pegida receives more attention, one can expect that this also leads to more people participating in related online activities. On average Pegida created seven posts per day, on which the users 
commented 2,524 times, and 43 news reports about Pegida were published per day. However, magnitudes for these measures vary substantially over time. To allow for comparisons, time series for posts, comments, and news reports were first smoothed by rolling means over 15 days to remove seasonality noise. Second, time series were normalized, such that value 0 (1) indicates minimum (maximum) activity. Figure 1 illustrates these normalized series in combination with annotations for important external events.

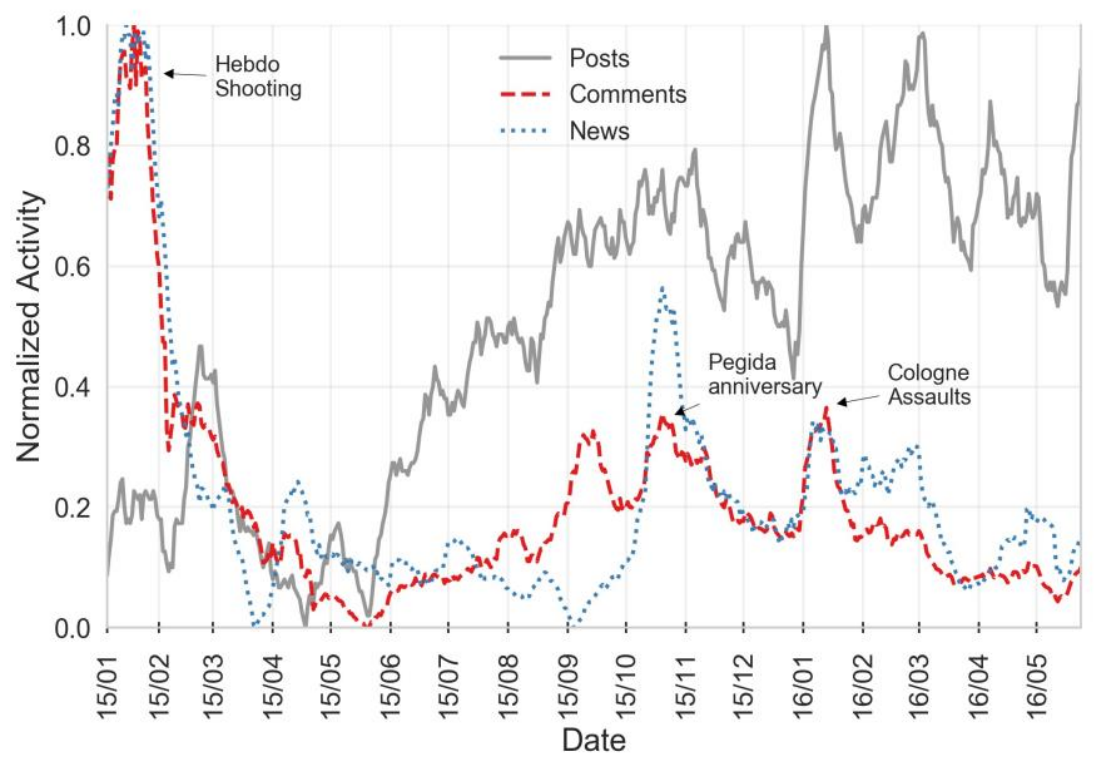

Figure 1. Normalized time series for posts, comments and news reports

As for the quantity of Pegida posts, the figure shows that Pegida continuously increased its content output over time. In contrast, the number of comments declined, reaching a peak in mid-January after the Charlie Hebdo shooting (10,000 daily comments), followed by a very low activity in consecutive months (2,000 daily comments). Overall, peaks in user activity are 
associated with external events. For instance, between October and November 2015, Pegida celebrated its extensively advertised anniversary.

In January 2016, the activity increased again after New Year's Eve sexual assaults on women in the German town Cologne, for which mostly Northern-African and Arabic men were held responsible in the media. Past research indicates that the topic of immigration and sexual violence became more salient after this event in German media outlets (Czymara and SchmidtCatran 2017). As will be shown below, the Cologne Assaults were also utilized by Pegida in order to legitimate its xenophobic agenda. Overall, data does not support the assumption that Pegida can increase user participation by simply creating more content, with a correlation of 0.10 (0.09 unsmoothed) between post and comment counts. Furthermore, the salience of Pegida as indicated by the relevant media coverage decreased over time. Major salience spikes correspond with those for user activity and are also related to external events.

Most importantly, there is a strong connection between public salience and user activity, with a correlation of 0.88 ( 0.59 unsmoothed) between news and comment counts. Regarding the question whether peaks in commenting activity are produced by only a small subset of Facebook users, Appendix F includes analysis on cumulative comment proportions and corresponding users. Results show considerable variance as the most active $1 \%$ of users generate almost one third of all comments. As a robustness check, I also used Facebook likes and shares instead of comments in order to provide alternative measures for user activity. The relation between likes and salience is somewhat weaker but nevertheless substantial, with a correlation of 0.56 ( 0.38 unsmoothed). Similarly, the correlation of news coverage and user shares is 0.37 ( 0.23 unsmoothed). As for the relation to the number of on-site protesters at Pegida events in Dresden, Supplementary Appendix C includes an additional comparison. It shows that attendance at protest events is also strongly connected to both Facebook activity as well as the news coverage of Pegida. 
To provide further evidence that user activities are more strongly related to external events than the content generation by Pegida organizers, granger hypothesis tests were applied. If user participation is caused by either an increase of Pegida posts or media coverage, these measures should have significantly more predictive power for participation than just using lagged values of participation in isolation. Table 1 shows test results in form of $F$ statistics and $p$ values for effects of Facebook posts and news articles on the number of Facebook comments. Results are displayed for included time lags between one and seven days, such that that earlier values of posts or news between one day up to one week are tested as predictors for user activity.

Table 1. Granger test results for predictors of user activity

\begin{tabular}{cccrc}
\hline Lags & Fposts & Pposts & Fnews & Pnews \\
\hline 1 & 0.961 & 0.327 & 1.329 & 0.250 \\
2 & 0.753 & 0.471 & 2.869 & 0.058 \\
3 & 1.861 & 0.135 & 14.155 & 0.000 \\
4 & 1.744 & 0.139 & 6.162 & 0.000 \\
5 & 1.573 & 0.166 & 7.786 & 0.000 \\
6 & 1.632 & 0.136 & 6.104 & 0.000 \\
7 & 1.511 & 0.161 & 11.025 & 0.000 \\
\hline
\end{tabular}

The table provides further evidence that the quantity of Pegida posts is not an important factor for explaining user activity. In comparison, for including time lags between three and seven days, Pegida's salience and attention in news reports provides significant predictive power for user activity on Facebook. However, these results need to be interpreted with caution and do not clearly indicate a causal relation, as this procedure does not control for other potential causes of user activity. In addition, the effect might also be reversed in a small number of cases. ${ }^{3}$ 


\section{What is in the news?}

The extraction of news reports not only allows to create a times series for analyzing Pegida's salience, but also the use of news reports to show in which context Pegida was a common subject within several time intervals. In doing so, it is possible to reveal important events for the movement and to examine its received attention at a given point in time. For this purpose, a support vector machine was used to find terms with the highest probability for correctly classifying news articles into corresponding time intervals. Supplementary Appendix A includes the top ten most distinguishing terms for each interval. In the first three months Pegida's name and stemmed terms for Islam criticism and Islamization were used more frequently in comparison to other intervals. This is not surprising as the movement was a rather new phenomenon and journalists used these terms to introduce Pegida to their readership. Other terms relate to important national and international events which were also utilized by the movement to warrant its position. For example, "charlie" in the first period was mentioned in articles about Pegida's reactions to the Charlie Hebdo shooting. Words for New Year's Eve in the fifth period were used in context of the Cologne Assaults. Shortly after, Pegida protesters used signs referring to refugees responsible for sexual assaults as "rapefugees". In later intervals, references to the refugee crisis, protests against refugee accommodations and between March/May 2016 also to the right-wing party AfD were dominant in news reports about Pegida.

\section{Topics and their variation over time}

After showing that Pegida is not able to influence user activity on Facebook by simply increasing its post output, an important question remains to be answered: Does it matter what kind of content is distributed? As described above, scholars observed that while Pegida's salience and the number of on-site protesters decreased over time, contents of speeches during Pegida demonstrations shifted to more extreme positions on Islam, the refugee crisis and other related topics (Patzelt 2016a). To analyze whether similar changes can also be observed for online content, a structural topic model was fitted on all available posts. This approach makes 
it possible to uncover latent themes and topical variation over time. For each topic, one example of a highly representative post by Pegida is available in Supplementary Appendix D. An overview of topic proportions and corresponding labels is illustrated in Figure 2.

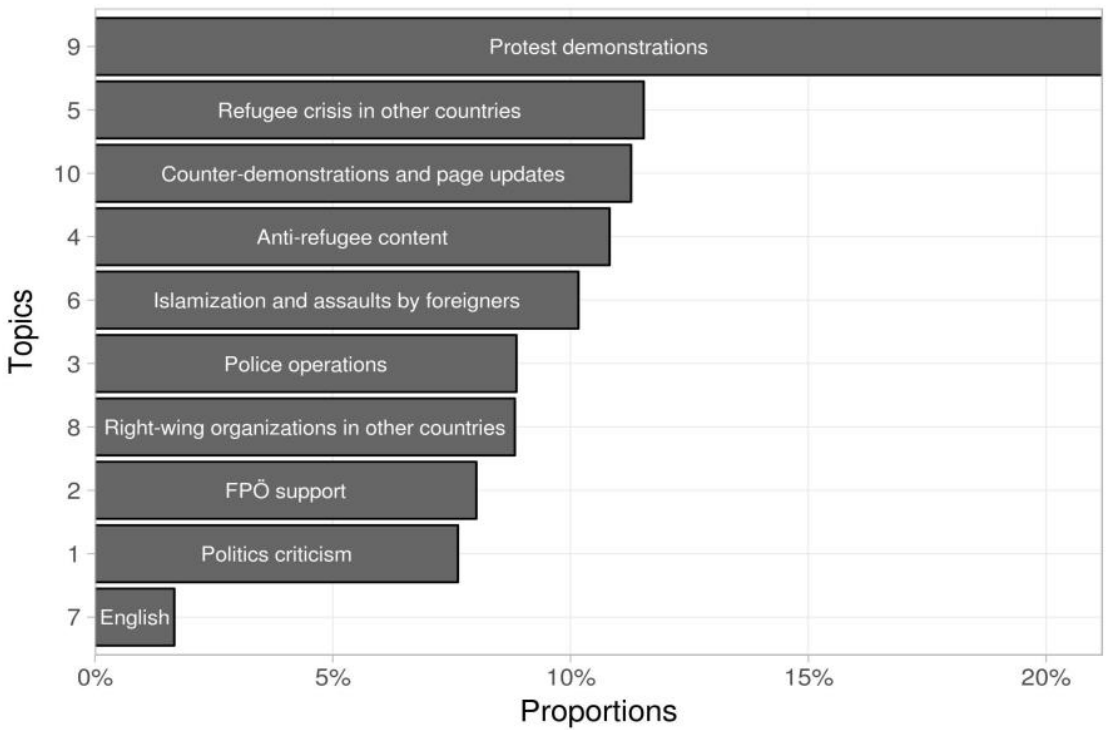

Figure 2. Topic proportions in Facebook posts by Pegida

Overall, more than $20 \%$ of Pegida's online content deals with demonstrations, which is not surprising, as this is the primary topic related to on-site mobilization. Also, references to the refugee crisis in countries other than Germany are common. Moreover, Pegida often distributes content about police operations in which predominantly foreigners were involved. Criticism of politicians, the government and elites in general is also apparent, as is Pegida's public support of the Austrian right-wing party FPÖ. Furthermore, Pegida generated a small number of English posts. A lot of content falls into a broader anti-refugee category, where foreigners and especially refugees are discriminated against. More than 10 percent of textual content are related to 
Islamization and foreigner assaults. Two of these topics are of special interest: firstly, the topic about demonstrations, as related posts are most important for Pegida to potentially mobilize online users and convince them to join protest demonstrations on the street. Secondly, the topic about Islamization and assaults by foreigners, as the analysis of news reports above demonstrated that foreigner assaults were an important issue for Pegida after the exogenous shock of the Cologne Assaults.

Table 2 lists translated terms for both topics that are frequently used and exclusive in both topics, determined by the FREX metric (Lucas et al. 2015, 19). Terms for the remaining topics are available in Supplementary Appendix D.

Table 2. Terms associated with topics about demonstrations and Islamization / assaults

\begin{tabular}{|c|c|}
\hline Demonstrations & Islamization/Assaults \\
\hline $\begin{array}{l}\text { watch, www.youtube.com, join, \#Legida, } \\
\text { livestream, thank, } \\
\text { \#DresdenShowsHowToDoIt, \#JoinUs, } \\
\text { theater_place, clock, \#dresden, monday, } \\
\text { face, patriot, tomorrow, youtube }\end{array}$ & $\begin{array}{l}\text { \#islamization, cologne, religion, christ, } \\
\text { muslim, mosque, school, islam, woman, } \\
\text { sexual, religious, book, paris, islamist, arab, } \\
\text { church }\end{array}$ \\
\hline
\end{tabular}

Pegida uses hashtags, asking supporters to join them in common places for demonstrations usually performed on Monday. In posts about demonstrations, the movement also includes links to corresponding live streams on YouTube. In comparison, the topic about Islamization and assaults by foreigners is strongly related to religious terms and includes references to New Year's Eve sexual assaults in Cologne. After the Cologne incidence, sexual assaults and other types of attacks by foreigners became a dominant theme in the German media. As described above, these assaults were also utilized by the movement to warrant its xenophobic position. To answer the second research question, how content of Pegida's posts changed over time, variations in topic proportions for demonstrations and Islamization / foreigner assaults are illustrated in Figure 3. 


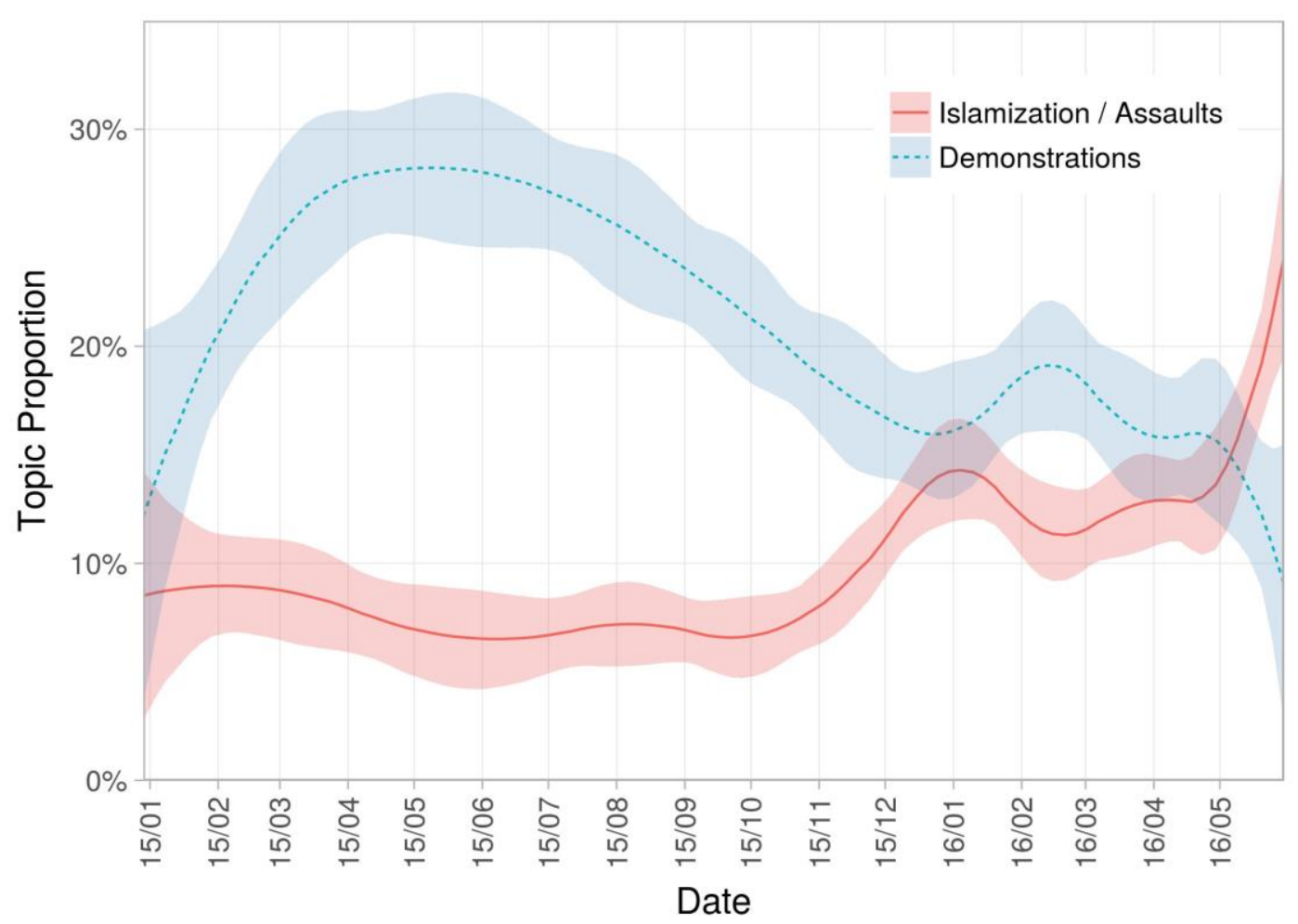

Figure 3. Estimates of topic proportions over time with $95 \%$ confidence intervals

The figure shows that over 25\% of Pegida's Facebook content issues demonstrations in the first months, but proportions are decreasing and reach a share of less than 10\% in May 2016. In contrast, Islamization and foreigner assaults were not a major topic in the early stages but increased over time. The topic had a midway spike after the Cologne Assaults and reached higher proportions in comparison to the demonstrations topic in the last months of observation. These results show that Pegida dynamically adjusts online content by posting less about demonstrations when its salience in the public sphere decreases. At the same time, the 
movement exploits external events by distributing more xenophobic and emotion inciting material.

\section{The relation between topics and user activity}

Is this change of topical content on Facebook working out for the radical movement? If true, posts that predominantly contain content about Islamization and foreigner assaults should result in more user activity than others, ultimately leading to an effective dissemination of rightwing propaganda. Assuming that the content of topics matters, this should hold even when accounting for time, which, as shown above, is strongly related to the salience of the movement. To analyze effects of the interaction between time and topic categories on user participation, topics with the highest corresponding proportions were identified for each post. Afterwards, negative binomial regressions were fitted, with the number of comments per post as a dependent variable and topic category in addition to time as explanatory variables. Regression tables for all models are given in Supplementary Appendix E. The full model with the best fit includes a flexible term for non-linear time trends and an interaction effect between topic and time. Results suggest that, in comparison to the reference topic on Islamization and assaults, most other topics generate less user activity. Even when controlling for time, posts about Islamization and assaults result in more users participating than for demonstration related posts. Figure 4 illustrates topic effects over time with estimates from the regression model.

The figure displays estimated comment counts for posts about demonstrations in comparison to posts about Islamization and assault. Through the whole observation period, comment estimates for posts about Islamization and assaults are higher than for mobilization posts about demonstrations. 


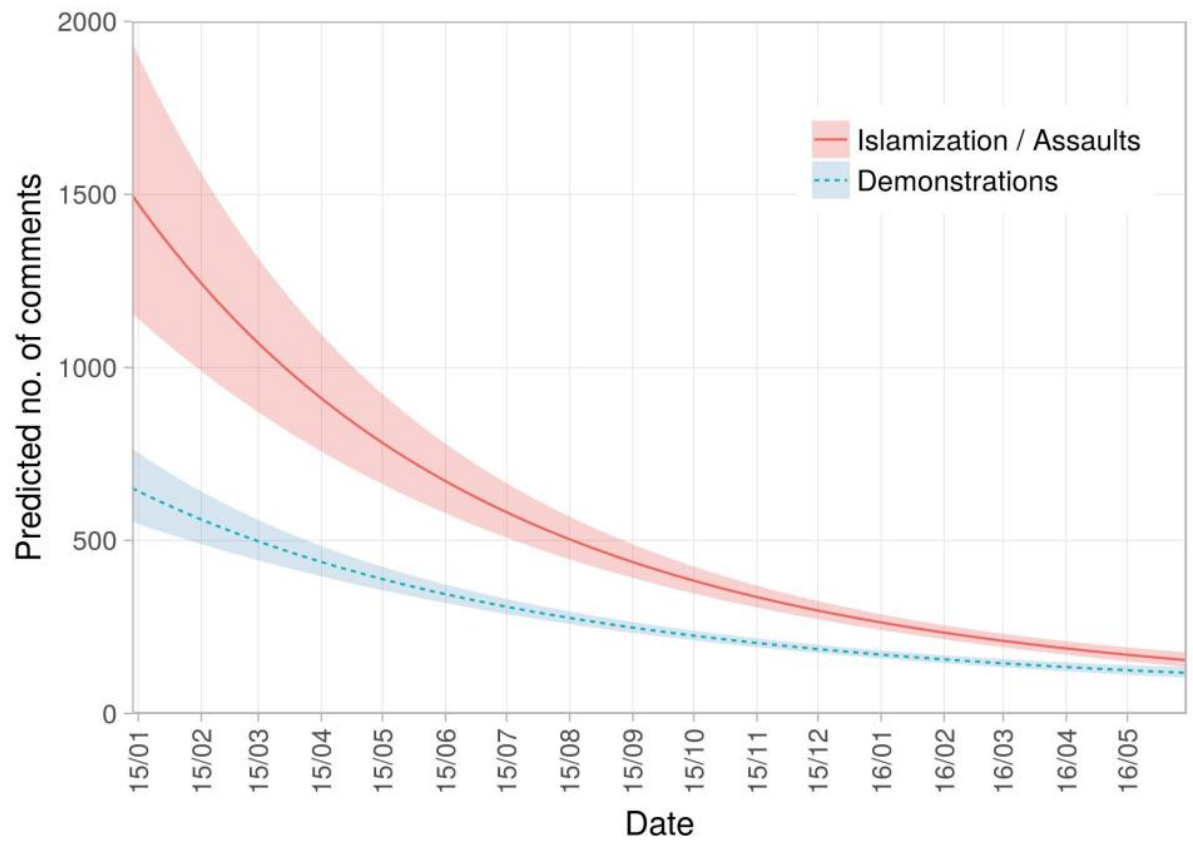

Figure 4. Predicted comment counts with $95 \%$ confidence intervals

Furthermore, user activity per post strongly decreases over time for both topics. This decrease is in line with timely dynamics for Pegida's received public attention and the number of protesters on the street. These results shows that, besides time as the most important factor, topical content of posts nevertheless does affect user activity on the platform and that xenophobic material leads to more activity than content related to protest mobilization. This is in line with the assumption that xenophobic posts are more likely to affect mood or emotion of Facebook users, which eventually also increases their need to express opinions by leaving a comment on the public page. Furthermore, these results provide further evidence for a more effective diffusion of radical and xenophobic content of right-wing actors in comparison to other content. 


\section{Conclusion}

Results of this work about the Facebook use of Pegida have shown that in order to understand factors influencing engagement on social media sites of right-wing movements, it is important to not only consider activities taking place on the platform itself. The public attention towards movements as measured with news reports and corresponding changes over time are of substantial importance for user engagement online. Although Pegida tried to create increasingly more content, high quantities alone do not lead to more user interactions, which are more strongly related the public attention that Pegida receives. Most importantly, it is the content of posts that matters. Over time, the movement created more xenophobic material about topics like Islamization and foreigner assaults, which is likely to trigger emotions such as fear and ultimately resulted in substantially more engagement in comparison to other topics. These findings show that Pegida resorted to more and more radical mobilization methods over time. Results are also in line with research on right-wing parties by Arzheimer \& Berning (2019) showing that the German party "Alternative für Deutschland" moved towards a radical right position by shifting their communication towards topics such as "Islam" and "refugees".

Although disentangling the causal relation between online activities and the public sphere is notoriously difficult, findings of this work further suggest a possible reinforcement process between the strategies of Pegida and the reactions of the audience: more radical posts lead to more user reactions and more reactions might eventually lead to more radicalized posts by the movement. However, the radicalized mobilization of the movement also leads to less mobilization from the public, since more radical methods do not appeal to an audience with moderate ideology. Over the long run, a lack of exogenous shocks that can be utilized to push xenophobic agenda, the radicalization of Pegida, and the establishment of the right-wing party "Alternative für Deutschland" are possible reasons for a declining supporter base. Nevertheless,

other factors such as political opportunity structures can also decrease support, which is why comparative research is required to better understand this connection. 
Are these changes in content distribution strategic in nature, and were thus planned by Pegida's leadership? As discussed in earlier, rational-choice motivated behavior theories fall short in addressing less rational motives and the role of emotions. However, the assumption of strategic choices is not in conflict with less rational and emotionally driven actions (Goodwin et al. 2004). Observations from this work support the assumption that strategic reasoning played an important role for content distribution. Firstly, as shown by a post in the results section, Pegida administrators know how social media features like hashtags and links can be utilized for increasing user activity and therefore the reach on Facebook. Secondly, when comparing context terms contained in Pegida-related news articles and topic changes within Facebook posts over time, results suggest that Pegida adapts Facebook content based upon which issues - if they can be exploited for xenophobic propaganda - are salient in the public sphere. Nevertheless, with no additional information about the administrators creating posts for Pegida, clear evidence about strategical expectations of Pegida's leadership is still missing. In order to fill this gap, interviews with leaders of right-wing movements could be a promising approach for future studies.

This case study also showed that research on social media usage of political groups can greatly benefit from incorporating media coverage. The dynamic measure of Pegida's salience used in this paper not only unfolded a strong connection with changes in user activity over time, but also shows potential reasons why the rightwing movement adjusted its social media strategy.

Despite these important insights, conclusions from this study are also constrained by limitations. While user activity is an important factor for shaping social media pages, it is not only relevant how often users interact, but in addition who participates in such debates. Due to Facebook's data policies, it is difficult to provide valid estimates of the sociodemographic attributes of its users. In addition, most comments on Pegida's page are by its supporters, but there is also a small number of people on the page who dislike Pegida and disagree with the position it takes. However, when it comes to reaching a maximum number of people for mobilization purposes, negative comments are still more useful than no activity at all, because 
mechanisms of information diffusion on Facebook apply regardless of user stance. With regards to the increasing use of radical mobilization methods by Pegida, this paper focused on the prevalence of related textual content. Future research could examine emotional reactions of users and to what extent the toning of posts became more negative or included even more extreme arguments over time.

Finally, the question remains to what extent findings of this study can be generalized to social media activities of other right-wing movements. As Pegida can be considered a typical rightwing populist movement with regards to anti-elitism, exclusion of outgroups and representation of "the people", findings of this work could hold for other social media presences of similar movements as well. At the very least, what we can learn from this study is that right-wing populist movements learned how to use social media platforms, but nevertheless have only limited influence on user engagement. It is also reasonable assume that user engagement for social media sites of other right-wing movements is high for content that is likely to trigger emotions, such as fear-inducing xenophobic material. However, it is still unclear whether the use of platforms like Facebook in times of decreasing public attention generally leads to increasingly radical mobilization methods of right-wing movements.

Utilizing Facebook data, this paper contributes to the literature by uncovering how right-wing movements use social media for mobilization and the dynamic interplay between content, public attention and user engagement. Unfortunately, Facebook recently closed its data interface for Facebook pages, limiting the potential for future studies on that matter. In an era where companies are increasingly restrictive about providing their data for scientific research, scholars need to find other ways of studying the social media use of right-wing movements. 


\section{Endnotes}

1. I used the R package stminsights to further inspect models with 20 and 30 topics (Schwemmer 2021). The model with ten 10 topics provided the best substantive fit.

2. The original version of the post in German language is available in Supplementary Appendix B.

3. In one case, a member of the Pegida leadership, Lutz Bachmann, posted a picture of him styled as Adolf Hitler, which went viral and received a lot of news coverage.

\section{Replication Files}

Replication materials for this publication are available at Harvard Dataverse: https://dataverse.harvard.edu/dataverse/cschwemmer

\section{References}

Arzheimer, K. (2015). The AfD: Finally a Successful Right-Wing Populist Eurosceptic Party for Germany? West European Politics 38(3): 535-556.

Arzheimer, K., \& Berning, C. C. (2019). How the Alternative for Germany (AfD) and their voters veered to the radical right, 2013-2017. Electoral Studies, 60, 102040.

Bene, M. (2017). Go viral on the Facebook! Interactions between candidates and followers on Facebook during the Hungarian general election campaign of 2014. Information, Communication \& Society 20(4): 513-529.

Bernstein, M.S., Bakshy, E., Burke, M. and Karrer, B. (2013). Quantifying the invisible audience in social networks. In: Proceedings of the SIGCHI Conference on Human 
Factors in Computing Systems - CHI '13. Association for Computing Machinery (ACM). ISBN 9781450318990, p. 21.

Budak, C. and Watts, D. (2015). Dissecting the Spirit of Gezi: Influence vs. Selection in the Occupy Gezi Movement. Sociological Science 2: 370-397.

Caiani, M., \& Parenti, L. (2016). European and American extreme right groups and the Internet. Routledge.

Connolly, K. (2014). Estimated 15,000 people join 'pinstriped Nazis' on march in Dresden. The Guardian. URL http://www.theguardian.com/world/2014/dec/15/dresden-policepegida-germany-far-right.

Crammer, K. and Singer, Y. (2001). On The Algorithmic Implementation of Multiclass

Kernel-based Vector Machines. Journal of Machine Learning Research (JMLR) 2(Dec): 265-292

Czymara, C.S. and Dochow, S. (2018). Mass Media and Concerns about Immigration in Germany in the 21st Century: Individual-Level Evidence over 15 Years. European Sociological Review 34(4): 381-401.

Czymara, C.S. and Schmidt-Catran, A.W. (2017). Refugees Unwelcome? Changes in the Public Acceptance of Immigrants and Refugees in Germany in the Course of Europe's 'Immigration Crisis'. European Sociological Review 33(6): 735-751.

Daphi, P., Rucht, D., Kocyba, P., Neuber, M., Roose, J., Scholl, F., Sommer, M., Stuppert, W. and Zajak, S. (2015). Protestforschung am Limit: Eine soziologische Annäherung an Pegida. WZB Berlin.

Dostal, J.M. (2015). The Pegida Movement and German Political Culture: Is Right-Wing Populism Here to Stay? Political Quarterly 86(4): 523-531.

Gadinger, F. (2019). Lügenpresse, gesunder Volkskörper, tatkräftiger Macher: Erzählformen des Populismus [Lying press, healthy folk bodies, energetic doers: narrative forms of populism]. In Narrative des Populismus (pp. 115-146). Springer VS, Wiesbaden. 
Gaisbauer, F., Pournaki, A., Banisch, S., \& Olbrich, E. (2021). Ideological differences in engagement in public debate on Twitter. Plos one, 16(3), e0249241.

Ganz, M. (2000). Resources and Resourcefulness: Strategic Capacity in the Unionization of California Agriculture, 1959-1966. American Journal of Sociology, 105(4), 1003-1062.

Goodwin, J., Jasper, J. M., \& Polletta, F. (2004). Emotional dimensions of social movements. The Blackwell companion to social movements, 413-432.

Granger, C.W.J. (1969). Investigating Causal Relations by Econometric Models and Crossspectral Methods. Econometrica 37(3): 424.

Grimmer, J. and Stewart, B.M.(2012). Text as Data: The Promise and Pitfalls of Automatic Content Analysis Methods for Political Texts. Political Analysis 21(617): 267-297.

Harlow, S. (2012). Social media and social movements: Facebook and an online Guatemalan justice movement that moved offline. New media \& society, 14(2), 225-243.

Helbling, M. and Tresch, A. (2011). Measuring party positions and issue salience from media coverage: Discussing and cross-validating new indicators. Electoral Studies 30(1): 174183.

Jasper, J. M. (2011). Emotions and social movements: Twenty years of theory and research. Annual Review of Sociology, 37, 285-303.

Kavada, A. (2015). Creating the collective: social media, the Occupy Movement and its constitution as a collective actor. Information Communication and Society 18(8): 872-886.

Klein, O., \& Muis, J. (2019). Online discontent: Comparing Western European far-right groups on Facebook. European societies, 21(4), 540-562.

Krämer, B. (2017). Populist online practices: the function of the Internet in right-wing populism. Information, Communication \& Society, 20(9), 1293-1309. https://doi.org/10.1080/1369118X.2017.1328520 
Kümpel, A. S., Karnowski, V., \& Keyling, T. (2015). News sharing in social media: A review of current research on news sharing users, content, and networks. Social media+ society, 1(2), 2056305115610141.

Lucas, C., Nielsen, R.A., Roberts, M.E., Stewart, B.M., Storer, A. and Tingley, D. (2015). Computer-Assisted Text Analysis for Comparative Politics. Political Analysis 23(2): 254277.

Mellon, J. (2013). Where and When Can We Use Google Trends to Measure Issue Salience? PS: Political Science \& Politics 46(02): 280-290.

Mudde, C. and Kaltwasser, C.R. (2017). Populism: a Very Short Introdction. Oxford University Press. ISBN 97801902348740190234873.

Opp, K.D. (2009). Theories of Political Protest and Social Movements: A Multidisciplinary Introduction, Critique, and Synthesis. London: Routledge.

Patzelt, W. and Klose, J. (2016a). PEGIDA. Warnsignale aus Dresden. Number 3 in Social coherence studies. Dresden: Thelem. ISBN 9783945363447.

Patzelt, W. (2016b). "Rassisten, Extremisten, Vulgärdemokraten!" Hat sich PEGIDA radikalisiert? Dresden.

Puschmann, C., Ausserhofer, J., \& Šlerka, J. (2020). Converging on a nativist core?

Comparing issues on the Facebook pages of the Pegida movement and the Alternative for Germany. European Journal of Communication, 35(3), 230-248.

Poell, T., Abdulla, R., Rieder, B., Woltering, R. and Zack, L. (2016). Protest leadership in the age of social media. Information Communication and Society 19(7): 994-1014.

Rathje, S. \& Van Bavel, J., \& van der Linden, S.. (2021). Out-group animosity drives engagement on social media. Proceedings of the National Academy of Sciences, 118(26).

Reiher, R. (2015). "WIR SIND DAS VOLK" [We are the People]. In A. Burkhardt \& K. Fritzsche (Ed.), Sprache im Umbruch (pp. 43-58). Berlin, Boston: De Gruyter. 
Rieder, B. (2013). Studying Facebook via data extraction. In: Proceedings of the 5th Annual ACM Web Science Conference on - WebSci '13. Association for Computing Machinery (ACM). ISBN 9781450318891, pp. 346-355.

Rieder, B., Abdulla, R., Poell, T., Woltering, R. and Zack, L. (2015). Data critique and analytical opportunities for very large Facebook Pages: Lessons learned from exploring “We are all Khaled Said”. Big Data \& Society 2(2): 205395171561498.

Roberts, M.E., Stewart, B.M., Tingley, D., Lucas, C., Leder-luis, J., Gadarian, S.K., Albertson, B. Rand, D.G. (2014). Structural Topic Models for Open-Ended Survey Responses. American Journal of Political Science 58(4): 1064-1082.

Schwemmer, C. (2018). stminsights. A 'Shiny' Application for Inspecting Structural Topic Models. URL https://cran.r-project.org/web/packages/stminsights/index.html.

Stier, S., Posch, L., Bleier, A. and Strohmaier, M. (2017). When populists become popular: comparing Facebook use by the right-wing movement Pegida and German political parties. Information Communication and Society 20(9):1365-1388.

Tilly, C. (1978). From Mobilization to Revolution. Reading, MA: Addison-Wesley Publishing Company.

Van de Donk, W., Loader, B.D., Nixon, P.G. and Rucht, D. (2004). Cyberprotest: New media, citizens and social movements. Routledge.

Van Laer, J., \& Van Aelst, P. (2010). Internet and social movement action repertoires: Opportunities and limitations. Information, Communication \& Society, 13(8), 1146-1171. Vorländer, H., Herold, M. and Schäller, S. (2015). Wer geht zu PEGIDA und warum? Eine empirische Untersuchung von PEGIDA-Demonstranten in Dresden.

Weaver, D. (1991). Issue salience and public opinion: Are there consequences of agendasetting? International Journal of Public Opinion Research 3(1): 53-68. 


\section{Supplementary Appendix: The Limited Influence of Right-Wing Movements on Social Media User Engagement}

\section{A. Newspapers}

\section{Newspaper Sources}

The following table shows the top 50 out of 114 newspapers used to measure issue salience, ordered by the number of articles.

\begin{tabular}{|c|c|c|c|}
\hline Newspaper & No. of articles & & \\
\hline Sächsische Zeitung Regionalausgaben & 2243 & Hamburger Abendblatt & 373 \\
\hline Sächsische Zeitung Stammausgabe Dresden & 1330 & Kölner Express & 365 \\
\hline Frankfurter Rundschau & 1069 & Berliner Morgenpost & 361 \\
\hline taz, die tageszeitung & 967 & SDA - Basisdienst Deutsch & 324 \\
\hline dpa-AFX ProFeed & 905 & SPIEGEL ONLINE & 293 \\
\hline Agence France Presse - German & 896 & Berliner Kurier & 263 \\
\hline Rheinische Post Duesseldorf & 85 & Allgemeine Zeitung & 247 \\
\hline Berliner Zeitung & 773 & ZEIT-online & 230 \\
\hline Der Tagesspiegel & 717 & Welt kompakt & 222 \\
\hline Frankfurter Neue Presse (Regionalausgaben) & 684 & B.Z. & 198 \\
\hline abendblatt.de - Hamburger Abendblatt Online & 622 & Die ZEIT (inklusive ZEIT Magazin) & 158 \\
\hline Kölner Stadt-Anzeiger & 606 & Wiesbadener Tagblatt & 156 \\
\hline Nürnberger Nachrichten & 582 & Wiesbadener Kurier & 156 \\
\hline Mitteldeutsche Zeitung & 533 & Main-Taunus-Kurier & 146 \\
\hline Stuttgarter Zeitung & 483 & Aar-Bote & 146 \\
\hline WELT ONLINE & 455 & Idsteiner Zeitung & 144 \\
\hline Aachener Nachrichten & 434 & Main-Spitze & 144 \\
\hline Berliner Morgenpost Online & 434 & Wormser Zeitung & 143 \\
\hline Aachener Zeitung & 426 & Neuss Grevenbroicher Zeitung & 137 \\
\hline Stuttgarter Nachrichten & 425 & Giessener Anzeiger & 132 \\
\hline
\end{tabular}




\begin{tabular}{lllr} 
Nürnberger Zeitung & 422 & Bergische Morgenpost & 125 \\
Kölnische Rundschau & 417 & Der Spiegel & 121 \\
General-Anzeiger (Bonn) & 415 & Lampertheimer Zeitung & 121 \\
Die Welt & 389 & Burstäadter Zeitung & 121 \\
Südwest Presse & 374 & Solinger Morgenpost & 119 \\
\hline
\end{tabular}

\section{Pegida related reports - most distinguishing words}

The following table includes ten most important terms for correctly assigning a news report to the corresponding time interval with a support vector machine.

\begin{tabular}{|c|c|c|c|c|c|c|}
\hline rank & $2014-12 / 2015-02$ & $2015-03 / 2015-05$ & $2015-06 / 2015-08$ & 2015-09/2015-11 & 2015-12/2016-02 & 2016-03/2016-05 \\
\hline 1 & neujahrsempfang & troglitz & verfassungsschutzbericht & galg & silvesternacht & afd \\
\hline 2 & Pegida & geert & flüchtlingsheim & jahrestag & flüchtlingskris & katholikentag \\
\hline 3 & islamkrit & wuppertal & heidenau & flüchtlingskris & silv & kinderschokolad \\
\hline 4 & charli & wild & flüchtlingsunterkunft & 1938 & russlanddeutsch & clausnitz \\
\hline 5 & islamisier & islamkrit & freital & transitzon & clausnitz & jena \\
\hline 6 & kathrin & gey & austritt & rek & connewitz & böhmermann \\
\hline 7 & demonstration & befreiung & ramadan & einjahr & europaweit & flüchtlingskris \\
\hline 8 & kogida & luck & alfa & gift & 59 & hof \\
\hline 9 & abendland & blockupy & jag & asylchaos & obergrenz & geldstraf \\
\hline 10 & ukrain & henkel & zeltstadt & schaff & warschau & hattk \\
\hline
\end{tabular}




\section{B. Pegida's awareness of social media functions}

The following text shows the German original version of the translated post in the results section which illustrates that Pegida knows about information diffusion functions of links and hashtags.

"Danke Kathrin! Du hast unsere Standpunkte sehr gut vertreten und Dich super gegen einen ständig ins Wort fallenden CDU-Spahn behauptet welcher vor Aggression und Arroganz nur so strotzte. Beim nächsten Mal gemeinsam mit Rene oder Lutz! Das war nur die erste Runde aber die ging klar an Dich! \#DresdenZeigtWiesGeht PS: An den dümmlichen Kommentaren auf irgendeiner Watch-Seite - der wir jetzt nicht durch links oder hashtags Reichweite verschaffen wollen - sieht man deutlich wie sie innerlich vor Wut über Kathrins souveränen Auftritt kochen. Man hatte dort vorher ein großes Desaster prophezeit. Tja abermals der Beweis das Gutmenschen einfach von nichts Ahnung haben." 


\section{Facebook Engagement and Pegida demonstrations in Germany}

The following graph includes normalized time series for Facebook engagement metrics, news articles and the number of on-site protesters of Pegida. Data for aggregated counts of protesters is not available on a daily basis, but instead aggregated per month. It was retrieved from the website durchgezaehlt.org, which is a website of researchers applying methods for estimating the number of protesters for Pegida and Legida demonstrations over time.

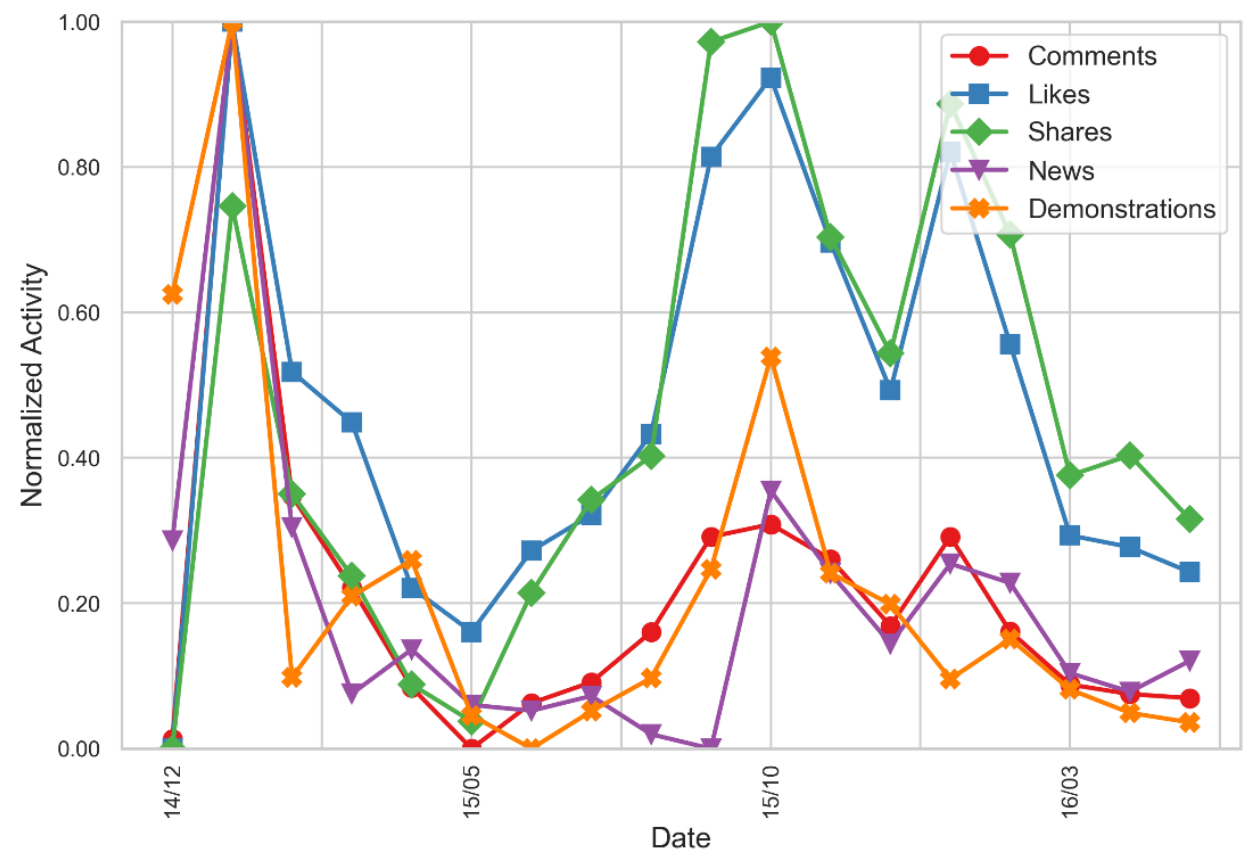




\section{Topic models}

\section{Frex Terms}

The following table shows the top 20 FREX terms for all topics not analyzed in the main article.

\begin{tabular}{|c|c|}
\hline Topic & FREX terms \\
\hline 1: Politics criticism & $\begin{array}{l}\text { merkel, cdu, angela, \#fastsonderschulersigmar, kanzlerin, } \\
\text { \#mischpokec, \#bundesinnenminis, \#claudiafatimaroth, } \\
\text { \#bundesgauckl, bundeskanzlerin, seehof, \#gohringeckardt, maas, } \\
\text { \#imerika, \#volksverrat, www.i-finger.d, spd, fluchtlingspolit, } \\
\text { \#ausdenpalastenjag, merkel }\end{array}$ \\
\hline 2: FPO support“ & $\begin{array}{l}\text { \#fpo, \#aufdiestrasseuberall, www.wiedenroth-karikatur.d, } \\
\text { \#tatjana4dresd, strach, \#kannstedirnichtausdenk, \#widerstand, } \\
\text { osterreich, fpo, hc, wahl, lauft, wild, \#dresden4tatjana, geert, freital, } \\
\text { erreicht, \#aufdenpunkt, hof, wien }\end{array}$ \\
\hline 3: Police operations & $\begin{array}{l}\text { schwed, polizist, polizei, tat, straftat, word, schwedisch, beamt, } \\
\text { verletzt, einzelfall, kam, flughaf, mehr, unterkunft, anwohn, thuring, } \\
\text { mess, berlin, stadt, wohnung }\end{array}$ \\
\hline 4: Anti-refugee content & $\begin{array}{l}\text { \#asylbetrugerraus, \#schengenaussetz, \#glucksritterzuruckverschiff, } \\
\text { arzt, eigent, wohl, haus, grun, gar, gerad, ingenieur, ide, leut, gern, } \\
\text { bunt, wirklich, gluck, tut, rein, lach }\end{array}$ \\
\hline $\begin{array}{l}\text { 5: Refugee crisis in other } \\
\text { countries }\end{array}$ & $\begin{array}{l}\text { turkei, ungarn, griechenland, \#verabschiedungskultur, griechisch, } \\
\text { migration, ungar, pass, syri, abschieb, russisch, migrant, viktor, } \\
\text { russland, milliard, orban, slowakei, fluchtling, idomeni, \#remigration }\end{array}$ \\
\hline 7: English posts / radio fees & $\begin{array}{l}\text { of, to, we, for, are, volksbegehren-sachsen.d, bord, frist, volksantrag, } \\
\text { \#ausgezahlt, and, amtsblatt, jorg, rundfunkstaatsvertrag, abgeb, on, } \\
\text { german, zustimm, sachsisch, ausfullen }\end{array}$ \\
\hline $\begin{array}{l}\text { 8: Right-wing organizations in } \\
\text { other countries }\end{array}$ & $\begin{array}{l}\text { niederland, frankreich, html, www.focus.d, franzos, prozent, bla, wenig, } \\
\text { europa , blick, bevolker, putin, erstmal, allerding, eben, sitz, } \\
\text { \#absurdistan, front, national, liegt }\end{array}$ \\
\hline 10: Counter-demos / page updates & $\begin{array}{l}\text { photo, updated, Pegida, friedlich, bitt, seit, cov, demo, fref, beweg, } \\
\text { link, lutz, dah, aktion, demonstration, their, post, zitat, spaziergang, } \\
\text { lug }\end{array}$ \\
\hline
\end{tabular}


Highly representative topic documents

This appendix contains one Pegida post in original German spelling for each of the ten topics analyzed in the main article. Examples are chosen to be highly representative for the corresponding topic, which is determined by MAP estimates of topic proportions from the structural topic model.

Topic 1 - Politics criticism

"Unglaublich... statt Schuldenabbau Rentenerhöhungen eine nachhaltige Familienpolitik oder Steuer-oder Lohnnebenkostensenkungen zur Entlastung mittelständischer Unternehmen geht alles in die Vollversorgung illegaler Einwanderer die durch einen nie dagewesenen Rechtsbruch der \#Merkeldiktatur in s Land geschleust werden!

\#IMErika und Ihre \#Volksverraterbände bekämpfen also Probleme die ohne sie nie dagewesen wären mit Geld welches das Volk fleißig erwirtschaftet hat \#MerktEuchDieNamen \#MerkelMussWeg \#FastSonderschülerSigmar \#ClaudiaFatimaRoth \#MischpokeCem \#GohringEckardt \#Bundesgauckler \#BundesinnenMisere \#AusDenPalästen-Jagen \#Volksverräter \#JudgementDay http://m.focus.de/magazin/kurzfassungen/focus-09-2016-milliardenueberschuss-desbundessoll-vollstaendig-in-fluechtlingskrise-fliessen-finanz-staatssekretaer-spahn-wir-wollen -die-schwarze-null-halten id 5318636.html"

Topic 2 - FPÖ support

“\#PEGIDA \#FPÖ \#Sensationell BRAVO" osterreich die ersten Hochrechnung sind da \#Hofer fuhrt mit großem Abstand! Auf in die Stichwahl da geht noch was!" \#ÖsterreichZeigtWiesGeht"

Topic 3 - Police operations

“\#PEGIDA \#DiskoTrauma \#Absurdistan \#Bereicherung Tja wenn man als \#Flüchtiger \#traumatisiert feiern geht kann man schon mal \#kulturell bedingt aufgrund der Trauer ob der 
zurückgelassenen Frauen und Kinder überreagieren ein sogenannter Einzelfall“* TM ..... (...)Massenschlägerei in Diskothek In der Nacht von Donnerstag zu Freitag hat es in einer Diskothek eine Schlägerei zwischen deutschen und syrischen Männern gegeben. Nach Informationen der Volksstimme handelte es sich bei den Deutschen um eine Gruppe von neun Polizeibeamten die in der Diskothek gefeiert hatten. Die Polizisten waren mit den Syrern in Streit geraten. Der Hintergrund der Auseinandersetzung ist noch unklar. Auf Nachfrage bestätigte eine Polizeisprecherin der Volksstimme dass es sich um Polizisten handelte. Die Syrer haben nach dem Streit das Lokal verlassen sind aber nach Zeugenaussagen mit Tischbeinen und Flaschen bewaffnet wiedergekommen und attackierten die Polizisten. Bei der Schlägerei wurden mehrere Personen verletzt.(...) http://www.volksstimme.de/lokal/magdeburg/20151211/ kriminalitaet-massenschlaegerei-indiskothek"

Topic 4 - Anti-refugee-content

"Das Gute an der ganzen gigantischen lächerlichen - Mainstream Medienoffensive zur Schmackhaftmachung angeblich traumatisierter Refutschiiiies ist dass immer mehr Leute die grottenschlechten Inszenierungen von ZDF und Co durchschauen. Da wird immernoch die arme Flüchtlingsfamilie mit Kind gezeigt obwohl jeder halbwegs denkende und mit gesundem Augenlicht gesegnete Bürger mittlerweile selbst die unendlichen Afrikaner-Horden bestehend aus kräftigen jungen Männern von 15-35 Jahren (natürlich alle aus Syrien zumindest mit syrischem Pass) ausgestattet mit modernster Technik und bestens gekleidet - in der eigenen Stadt gesehen hat und weiß wie sie sich verhalten. Da werden Unmengen an Geld verpulvert damit B/C/D/E-Prominente sich für die gescheiterte Asylpolitik von \#IMErika und \#FastSonderschülerSigmar aussprechen und Betroffenenheit vorgaukeln. Aus dem Artikel: überflüssigster Teil der prominenten Selbstbeweihräucherung war dabei wohl die LiveSchalte zu Til Schweiger nach Moskau der fleißig über die Erfolge der Til Schweiger Foundation berichten durfte - als ob die im Studio anwesenden Prominenten nicht ausreichend waren und die Medien nicht schon für genug Aufmerksamkeit für Schweiger gesorgt hätten.. \#MerktEuchDieNamen \#AsylbetrugerRaus \#GlücksritterZurückverschiffen \#SchengenAussetzen \#GrenzenDicht \#PEGIDA \#TilSchweiger \#TilUndSigmar \#TilDo 
\#AusGEZahlt \#Lügenpresse \#LügenZDF \#Kerner

http://m.welt.de/vermischtes/article146250293/ZDF-Fluechtlingsgala-wird-zum-totalen$\underline{\text { Reinfall.html" }}$

Topic 5 - Refugee crisis in other countries

“\#PEGIDA \#OrbanViktor \#Fidesz \#GrenzenDIcht \#Ungarn \#Hungary (...) Ungarn Orban will keine Flüchtlinge mehr durchs Land lassen Ungarn will jetzt auch an der Grenze zu Rumänien einen Zaun errichten. Es sei bereits alles vorbereitet sagte Ministerpräsident Orban in einem Rundfunk-Interview. Grundsätzlich sollten gar keine Flüchtlinge mehr durch sein Land kommen. Ungarn hatte bereits im Herbst die Übergänge zu Serbien und Kroatien abgeschottet.(...) Viktor Orban weiß was auf Europa zukommt wenn der Frühling einkehrt und das Mittelmeer ruhiger wird. (y) Und er handelt für sein Land und sein Volk Bravo Herr Orban Köszönöm szépen!

http://www.deutschlandfunk.de/ungarn-orban-will-keine-fluechtlinge-mehrdurchs-land$\underline{\text { lassen.1947.de.html?drn:news id=572509" }}$

Topic 6 - Islamization and assaults by foreigners

“\#PEGIDA \#InformiertEuch \#SchautHin Text von Sabatina James: Das Attentat auf Christen in Pakistan und die Terrorattacken von Brüssel und Paris sind keine Ausnahmen mehr. Sie sind Teil einer grausamen Kette von Massenmorden die immer länger und blutiger wird. Der westlichen christlichen Welt ist einseitig Krieg erklärt worden vor Jahren schon. Und mit jedem Jahr nimmt dieser Krieg an Intensität zu. Europa will es nicht wahrhaben dass Samuel

Huntingtons exakt vor 20 Jahren veröffentlichtes Buch vom Kampf der Kulturen und seinen 
Bruchlinienkonflikten“ grausame Realität geworden ist. Und doch wirkt die Verdrängung des islamischen Großangriffs zusehends naiv. Denn die Schlachtfelder dieses Krieges sind blutiger als es unsere Abendnachrichten erahnen lassen. Alle Ränder der islamischen Welt sind blutig geworden. Von Indonesien und den Philippinen ganz im Osten bis zur Elfenbeinküste ganz im Westen wo vor wenigen Tagen zwei Dutzend Tote bei Angriffen auf westliche Hotels gemeldet wurden."

Topic 7 - English posts and protest against radio fees

"PEGIDA - 10 demands to the German asylum politics 1.) We call for an immediate stop for asylum seekers and we call for a German asylum-emergency law - now! Our asylum laws were conceived after the war for manageable quantities of approximately 2000 refugees per year and not for 15 millions we expected to reach already in 2015! 2.) We call for strict border controls! We demand to suspend the Schengen Agreement IMMEDIATELY - for all the borders of Germany! Other EU countries control their national borders - and that although the completely failed Dublin procedure goes almost entirely at the expense of Germany. The temporary reintroduction of border controls during the $\mathrm{G} 7$ summit has proved that border controls are an appropriate mean to prevent illegal border crossings the flourishing business of smuggling mafia and the entry of criminals. 3.) We demand that the group of safe countries of origin will be expanded on ALL Council of Europe member countries! This European Council has 47 member countries with 830 million citizens and over 1800 European officials. All Member States have committed themselves to the preservation of democracy and rule of law as well as the recognition of the fundamental and human rights. That should be enough to count these countries to safe countries! 4.) We call for a TEMPORARY right of asylum for refugees of war! Of course real war refugees and accepted asylum seekers is to grant temporary protection and full coverage in the modest scale. But once the situation in the country improves the refugees have to leave our country again. 5.) We call for a binding limit for the annual reception of asylum seekers namely defined by ourselves the host country Germany! This vital question about the future of our country must be carried out by means of direct democracy through a referendum! 6.) We finally demand honesty in the integration debate and the end of the red-green social-romantic tale of wanting to integrate masses of male African asylum seekers here! No one wants that. The green socialists use the refugees to 
create a red-green job wonder for bachelor graduates of chatter Sciences here. The pathological altruism and feigned empathy gooders are moral invisibility cloaks which should cover the mega-lucrative migrant market. 7) We demand that immediately all rejected asylum seekers and hundreds of thousands of illegal immigrants to be banished at once! Again: We call MASS deportations - and do it now! 8) We demand that the refugee problem has to be resolved in locally in their own cultures! Our so-called representatives of the people should finally show backbone and take Saudi Arabia Qatar and the United Arab Emirates in charge. These wealthy huge Sharia-paradises are much better suited to accommodate the crowds of Muslim asylum seekers as an Europe of unbelievers! And we finally need asylum procedurespot audits in the countries of origin. Even in North Africa has to be decided by fast-track procedure on applications for asylum in Germany! 9.) We demand that foreign criminals which are connected with Islamic terrorist organizations are banished immediately! This naturally also includes the adopted sons and daughters of German Minister of Internal Affairs de Maiziere all these jihad returnees and all known and violent Salafists - these people are to be deported outside Europe immediately! 10.) There will be expected resistance from Brussels about any changes in our German asylum policies - so then we all have to leave this bullying dump EU! The future French President Marine Le Pen has summarized it in the destruction of these EU - quote. It's only this radical way which works! These EU will never be to reform who should himself rationalize his highly-paid job? Asylum seekers driven by nothing than economical reasons - are NOT welcome! Christian refugees specially those who are surpressed by slaughtering Islamists are absolutely welcome in Germany and we provide every shelter food and life-support they need because this belongs to the German helping nature. To all others: STAY OUT! We the people of European nations need to unite to conserve and to defend our values our culture our freedom. We need to unite against the selfdeclared kings and queens in Brussels. We the German people need international support against our own politicians in our German parliaments. Our politicians want to change the form of government of the Federal Republic of Germany they want to abolish the German state people in Germany to replace us by a multicultural society they want to establish a multiethnic state on German soil - this is a behavior like high traitors! \#PEGIDA" 
Topic 8 - Right-wing organizations in other countries

“(...)Europas Rechte schließen sich zusammen Le Pen Vilimsky und Wilders formieren sich zu einer EU-Fraktion. Was das finanziell und rechtlich bringt.(...) Na endlich für die FREIHEIT!! (y) Deutschland wird folgen! (...) Lange wurde daran gebastelt nun haben sich die Rechtspopulisten Europas im EU-Parlament tatsächlich zu einer Fraktion zusammengeschlossen. Heute wurde sie in Brüssel von Harald Vilimsky (FPÄ) Marine Le Pen und Geert Wilders präsentiert. Es ist historisch verkündete Wilders. Bereits gestern wurde auf Twitter die Gründung der Fraktion angekündigt. Der Name ist Europa der Nationen und der Freiheit . Im vergangenen Jahr war der Plan noch gescheitert weil es Marine Le Pen nicht gelang Parlamentarier aus genugend EU-Ländern zu gewinnen. Zur Bildung einer Fraktion im Europaparlament sind 25 Abgeordnete nötig die in mindestens sieben Mitgliedstaaten gewählt sind. Die Front National war bei der Europawahl in Frankreich stärkste Partei geworden und stellt derzeit 23 Abgeordnete. Neben Frankreich Österreich und den Niederlanden sind Parteien aus Italien Großbritannien Belgien und Polen dabei.(...) \#PEGIDA \#FürDieFreiheit http://kurier.at/politik/eu/rechte-fraktion-im-eu-parlament -europas-rechte-schliessen-sichzusammen/136.376.617"

Topic 9 - Demonstrations

“+++ Montag ist es wieder soweit. +++ GESICHT ZEIGEN! 07.03.2016 - 19 UHR Richard-Wagner-Platz Leipzig. Treffpunkt zur sicheren Anreise wie immer: Ab 18:30 Hauptbahnhof Leipzig vor McDonalds. Gemeinsam SICHER zum Richard-Wagner-Platz! Redner am Montag: LUTZ BACHMANN SIEGFRIED DAEBRITZ FRIEDRICH FRÖBEL einige weitere... Teilt die Veranstaltung! Bringt eure Freunde / Nachbarn / Arbeitskollegen mit! Es geht um unser Land / unsere Zukunft und die Zukunft unserer Kinder! \#LEGIDA \#PEGIDA \#AufDieStraße https://www.facebook.com/events/1080481985319052/D10" 
Topic 10 - Counter-demonstrations and page updates

"Nochmal der Aufruf! Am Sonnabend den 14.3.2015 wird PEGIDA die friedliche GEGENDEMO gegen Pierre Vogel und seine Salafisten sein. (Y) Also jeder der kann ab noch Wuppertal! Den Link zur Veranstaltung findet ihr im ersten Kommentar. like“Emoticon"

TEILEN und EINLADEN! :-) Es werden noch ORDNER gesucht bitte melden und keine Angst das ist keine Zauberei. (Y) Hier ein Link zu dieser Gruppe:

https://www.facebook.com/groups/377245535788683/?fref=ts Schreibt dem Administrator Chris Ko:

https://www.facebook.com/christian.konig.330

Hier eine Möglichkeit Fahrgemeinschaften zu bilden! (Y)

https://www.facebook.com/groups/1804474533110935/" 


\section{Topic Proportions over Time}

The following graph illustrates proportions over time for all topics not discussed in detail in the main paper:
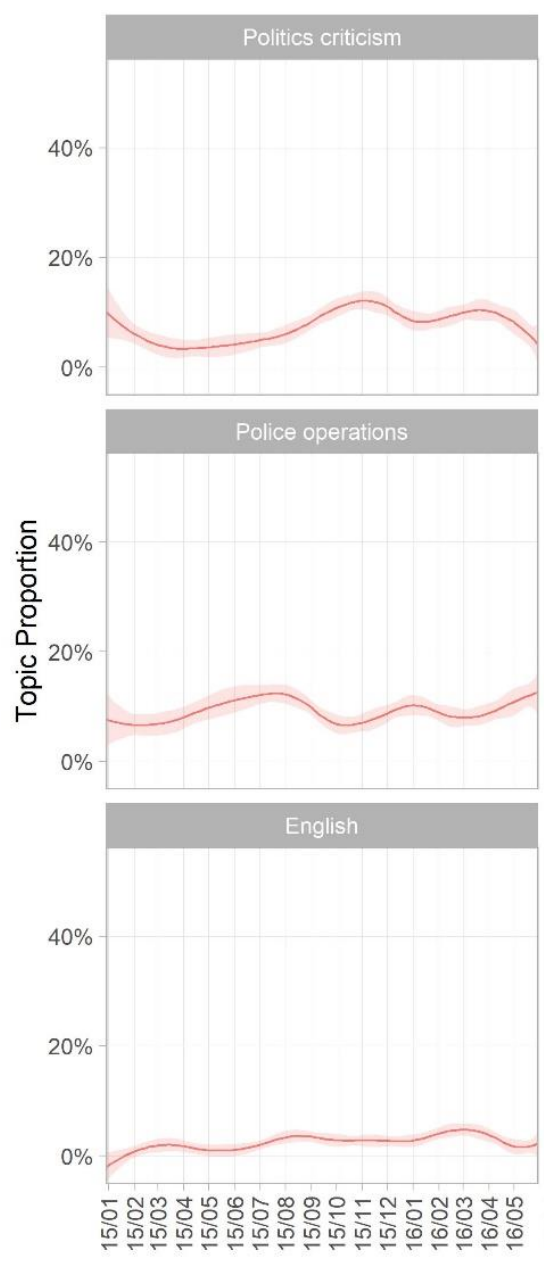
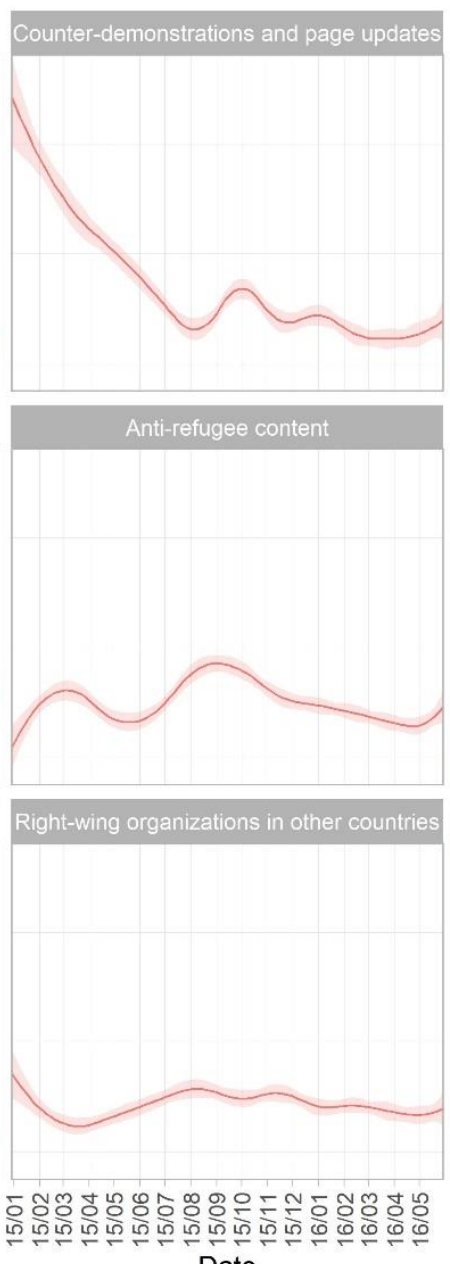

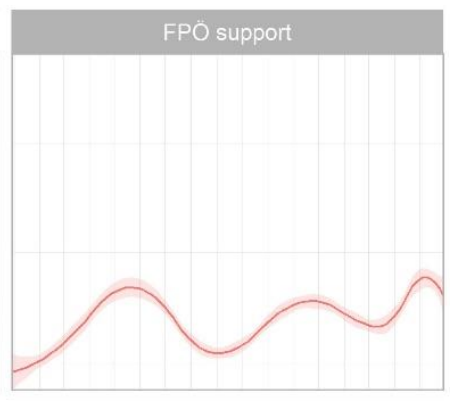

Refugee crisis in other countries

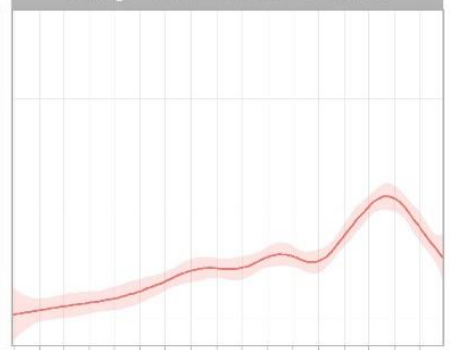

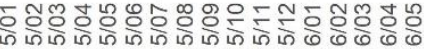

\section{Date}




\section{E. Predicting user engagement for Pegida posts}

The following table shows nested negative-binomial regression models for the number of user comments each Pegida received.

\begin{tabular}{llll}
\hline Variables & \multicolumn{3}{l}{ Only Topics Topics \& Date Full Model } \\
\hline Intercept & $5.85 * * *$ & $7.05 * * *$ & $7.19 * * *$ \\
& $(0.05)$ & $(0.06)$ & $(0.12)$ \\
Politics criticism & -0.13 & -0.02 & $-0.64 * *$ \\
FPÖ support & $(0.08)$ & $(0.07)$ & $(0.22)$ \\
& $-0.55 * * *$ & $-0.35 * * *$ & $-0.89 * * *$ \\
Police operations & $(0.08)$ & $(0.07)$ & $(0.21)$ \\
& $-0.18 *$ & $-0.17 * *$ & $-0.78 * * *$ \\
Anti-refugee content & $(0.07)$ & $(0.07)$ & $(0.18)$ \\
Refugee crisis in other countries & 0.10 & -0.03 & $-0.61 * * *$ \\
& $(0.07)$ & $(0.06)$ & $(0.17)$ \\
English & $-0.38 * * *$ & $-0.16 * *$ & -0.31 \\
Right-wing organizations in other countries & $(0.06)$ & $(0.06)$ & $(0.19)$ \\
Protest demonstrations & -0.13 & -0.14 & 1.03 \\
Counter-demonstrations and page updates & $(0.17)$ & $(0.16)$ & $(0.62)$ \\
& 0.15 & $-0.17 *$ & -0.07 \\
& $(0.08)$ & $(0.07)$ & $(0.19)$ \\
& $-0.32 * * *$ & $-0.51 * * *$ & $-0.82 * * *$ \\
& $(0.06)$ & $(0.05)$ & $(0.14)$ \\
& $(0.07)$ & $(0.06)$ & $(0.14)$ \\
& & & \\
& & 0.01 & 0.19 \\
& & &
\end{tabular}


Date

$-0.00 * * * \quad-0.00 * * *$

(0.00)

(0.00)

Politics criticism x Date

$0.00 * *$

(0.00)

FPÖ support x Date

$0.00 * *$

(0.00)

Police operations x Date

$0.00 * * *$

(0.00)

Anti-refugee content x Date

$0.00 * * *$

(0.00)

Refugee crisis in other countries x Date

0.00

(0.00)

English x Date

$-0.00 *$

(0.00)

Right-wing organizations in other countries x Date

$-0.00$

(0.00)

Protest demonstrations x Date

$0.00 *$

(0.00)

Counter-demonstrations and page updates x Date

$-0.00 * * *$

(0.00)

\begin{tabular}{lllc}
\hline AIC & 50621.86 & 49568.82 & 49464.94 \\
BIC & 50690.35 & 49643.53 & 49595.69 \\
Log Likelihood & -25299.93 & -24772.41 & -24711.47 \\
Observations & 3.738 & 3.738 & 3.738 \\
\hline
\end{tabular}

*** $\mathrm{p}<0.001 ; * * \mathrm{p}<0.01 ; * \mathrm{p}<0.05$, standard errors in parenthesis 


\section{F. Comment activity}

The following visualization includes cumulative percentages of Facebook comments and users creating these comments. It becomes apparent that a small number of users produced a large number of comments. For instance, the most active $1 \%$ of users generated $32 \%$ of all comments.

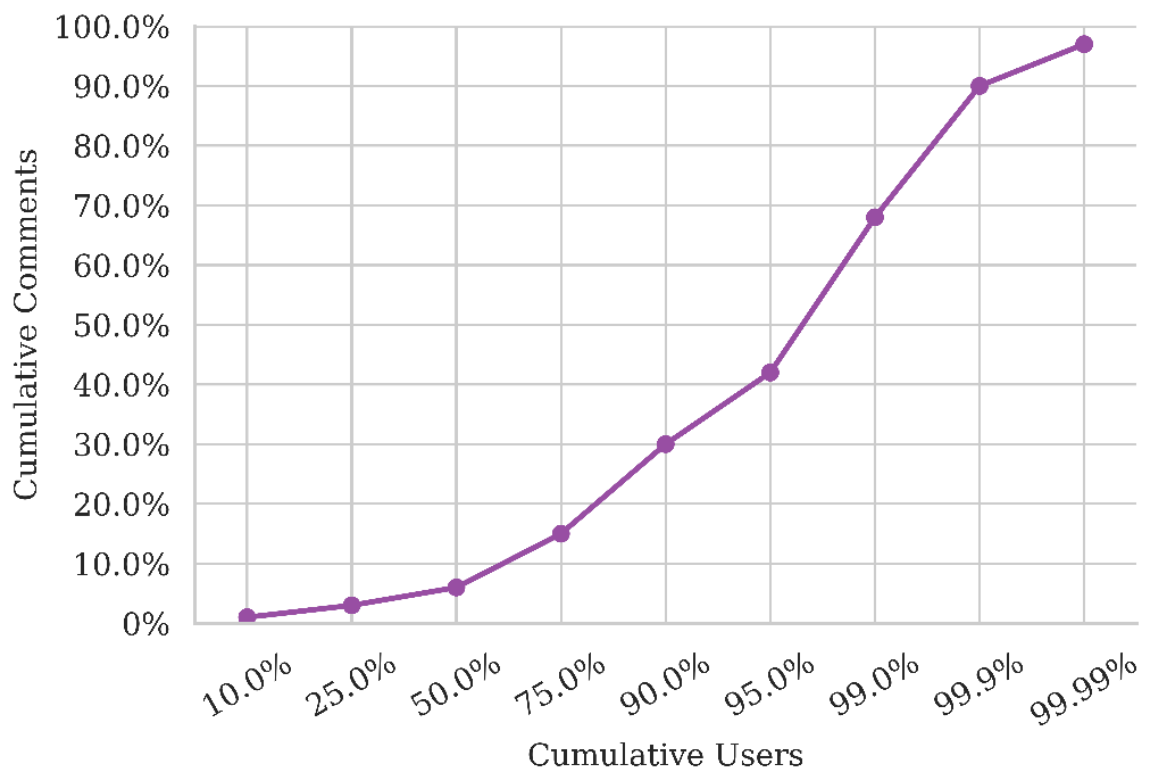

